\title{
Scheduling Trickle Irrigation Using Soil Matric Potential for"Le Conte" Pear Trees Planted in Calcareous Soils
}

\author{
Abd El-Messeih, W.M ${ }^{1}$ and R.W. El- Gendy ${ }^{2}$
}

\begin{abstract}
The present research was carried out in 2007 and 2008 years on 6 years old of "Le Conte" pear trees grafted on communis rootstock and grown in calcareous soil at Burg El-Arab region, Alexandria Governorate. The objective of this work was to investigate the effect of three irrigation rates based on soil matric potential measurements, which was as: (T1): high irrigation rate (300 to -500 mbars), (T2): medium irrigation rate (-500 to 820 mbars) and (T3): low irrigation rate $(-820$ to -1762 mbars), on: vegetative growth, leaf chemical content, yield, fruit quality and water use efficiency (WUE).

The main results of this work can be summarized in the following points:

- Trees grown under (T1) ( from 100 to $80 \%$ of A.W), were significantly produced high shoot length, shoot diameter, leaf area fruit yield, high fruit quality ( F. length, diameter \& weight) and gave higher water use efficiency (WUE). Also, these trees gave the highest leaf mineral composition ( $\mathrm{N}, \mathrm{P}, \mathrm{K}, \mathrm{Ca}, \mathrm{Mg}, \mathrm{Fe}, \mathrm{Mn} \&$ Zn) and leaf total chlorophyll followed by (T2) ( from 80 to $60 \%$ of A. W) \& (T3) ( from 60 to $40 \%$ of A.W) for the two seasons.

- On the other hand, trees grown under (T3) produced significantly high leaf free proline with fruits of highest firmness, acidity \%, TSS\% and total sugars\% followed by those grown under (T2) and (T1) respectively, in the two studied seasons.

- Based on the above general results, the irrigation treatment (T1) is recommended for the irrigation of "Le Conte" pear trees planted in calcareous soil at Burg El- Arabe region (Egypt) using the trickle irrigation system scheduled via the soil matric potential measurement using tensiometers.
\end{abstract}

Keywords: Scheduling Irrigation, Trickle irrigation system, Soil matric potential, pear trees, leaf mineral composition, water use efficiency.

\section{INTRODUCTION}

Of all the materials used by fruit trees for growth and pears as well, water is taken up in the largest amount. The evaporated water in a well- watered tree is replaced by absorption from the soil. if absorption is insufficient to replace evapotranspiration losses, the water status of the tree is changed, its "water potential" is lowered, and many of its life processes are affected, like influencing cell division and expansion; flower bud differentiation; and decreasing carbohydrate production through altering stomatalaperture and enzyme activities of photosynthesis and respiration. On the other side, waterlogging around plant roots create undesirable conditions, causing a negative effects on root activities.

In Egypt, both of water and food are in short supply, farmers already have to learn how to use water in the most efficient way possible to get maximum production from each unit of water and land. Several methods have been used to estimate plant requirement. The comparative merits of these methods for estimating evapotranspiration of fruit trees have been reviewed by (Elfving, 1982). It is critical to satisfy the water requirement to fruit trees at the beginning of the growing season when fruit set occurs, during the period of flower bud formation, and when the final fruit swell occurs before harvest. It has been known for a long time that drought lowers productivity in fruit trees, what is now beginning to be understood is that water use is directed related to productivity even under conditions when the trees are not visibly stressed from drought. Dry- weight increases in apple (Gyuro, 1974) and peach (Richards, 1976; Richards and Rowe, 1976) are proportional to the amount of water transpired. The fact water use, directly and proportionally, affects yield makes water relations a central issue in fruit production and fruit tree physiology. If soil and plant water potentials are used to indicate irrigation needs, however, the irrigator does not know anything about the amounts of water in the soil i. e., the percent of available moisture, or the amounts used by the plants. Instead of detailed information about amounts of water. The matric potential methods utilized only two easily acquired units of information. One is the matric potential in the field at defined depth. These data are as simple and easy to obtain as reading on the dial of a manometer or moisture block meter. The other involves knowing what these readings would be when the crop is irrigated (Taylor, 1965). Records of matric potentials taken at frequent time intervals provide a means of evaluating and prescribing when and how much water should be applied without reference to soil moisture content.

\footnotetext{
${ }^{1}$ Nubaria Hort. Res. Hort. Res. Instit., Agric. Res. Center, Egypt.

${ }^{2}$ Soil \&Water Res. Dept. Nuclear Res. Center, Atomic Energy

Authority, Cairo, Egypt.

Received June1, 2009, Accepted June21, 2009
} 
The main objective of the present investigation was to study the influence of soil matric potential treatments on the vegetative growth, leaf chemical composition, yield and fruit quality of " Le Conte" pear trees under calcareous soil condition beside, saving irrigation water via irrigation scheduling, using drip irrigation system.

\section{MATERIAL AND METHODS}

This work was carried out at Burg El- Arab region , Alexandria Governorate, during two successive seasons, (2006- 2007) and (2007 - 2008) on 6 years old of "Le Conte" pear trees ( Pyrus communis. L. $\times$ Pyrus pyrifolia. N.) on communis rootstock planted on a calcareous soil. Some soil properties of the experimental site are shown in Table (1). The treated trees were spaced at 5X6 meters apart. The trees were selected to be healthy and similar in their vigor, as possible, and treated with normal agricultural practices. There were two lateral lines of drip irrigation system for each row of the trees on the two opposite sides. Four emitters per tree $(8 \mathrm{~L} / \mathrm{h})$ installed on the lateral line in a location opposite to tree trunk at $50-\mathrm{cm}$ from tree trunk. 50-cm distance was between the two emitters and one meter between lateral lines. Thirty six trees were chosen for the present investigation.

To calculate the quantity of applied water for irrigating the pear trees, a soil moisture retention curve (SMRC) as shown in Fig (1) was determined for the whole soil profile till $150 \mathrm{~cm}$ depth using pressure plate apparatus in laboratory according to (Black, 1965).

SMRC's model was obtained for this curve using van Genuchten (1980). This model was used to obtain the soil moisture content at 330, 500, 820 and 1762 mbar to calculate quantities of applied water for irrigating the three treatments of soil matric suction (Table 2). van Genuchten model (1980) is as the following:

$\theta_{\mathrm{h}}=\theta_{\mathrm{r}}+\left(\theta_{\mathrm{s}}-\theta_{\mathrm{r})}\left[1+(\alpha \mathrm{h})^{\mathrm{n}}\right]^{-\mathrm{m}}\right.$

Where: $\theta_{\mathrm{h}}$, is the volumetric soil moisture content at $\mathrm{h}, \mathrm{mbar}$.

$\theta_{\mathrm{r}}$, is the volumetric residual soil moisture content.

$\theta_{\mathrm{s}}$, is saturation point on volume fraction.

$\alpha$, is the inverse of the air entry suction $\left(h_{b}\right)$, and

$\mathrm{n} \& \mathrm{~m}$, are constants of the fitting curve.

Soil matric potential (h) could be obtained via rewrite the model in $\mathrm{h}$ as function to $\theta$ as shown in model 1 El Gendy 2006:

$h=-h_{b}\left[\left(\frac{\theta-\theta_{r}}{\theta_{s}-\theta_{r}}\right)^{-\left(\frac{1}{m}\right)}-1\right]^{\frac{1}{n}}$

Where:

$h_{b}$, is air entry suction $(1 / \alpha)$

The soil bulk density (BD) was determined for 0 $15,15-30,30-45,45-60,60-75,75-90,90-105$, 105$120,120-135$, and $135-150 \mathrm{~cm}$ depths using a soil cylinder $(5-\mathrm{cm}$ in diameter and $10 \mathrm{~cm}$ in height) according to Black (1965).

\section{Irrigation Treatments:}

Irrigation treatments (Table:2) were calculated from SMRC and its model (fig.1) according to van Genuchten (1980). The same treatments were used in the two years of study.

Mercury Tensiometers were used to control irrigation process in the first two treatments but the third treatment was controlled by detecting volumetric water content to reach at $13.98 \%$ ( equals to 1762 mbar) using model 1 El Gendy (2006) because tensiometer is not valid over 850 mbar. Tensiometers were installed at $55 \mathrm{~cm}$ depth beside the emitter in each treatment.

The experimental treatments were arranged in a complete randomized block design and the treatment was replicated in 6 times in each replicates, i.e. 3 treatments X 6 replicates $X 2$ experimental unit $=36$ trees.

Table 1. Some soil physical and chemical properties of the experimental site

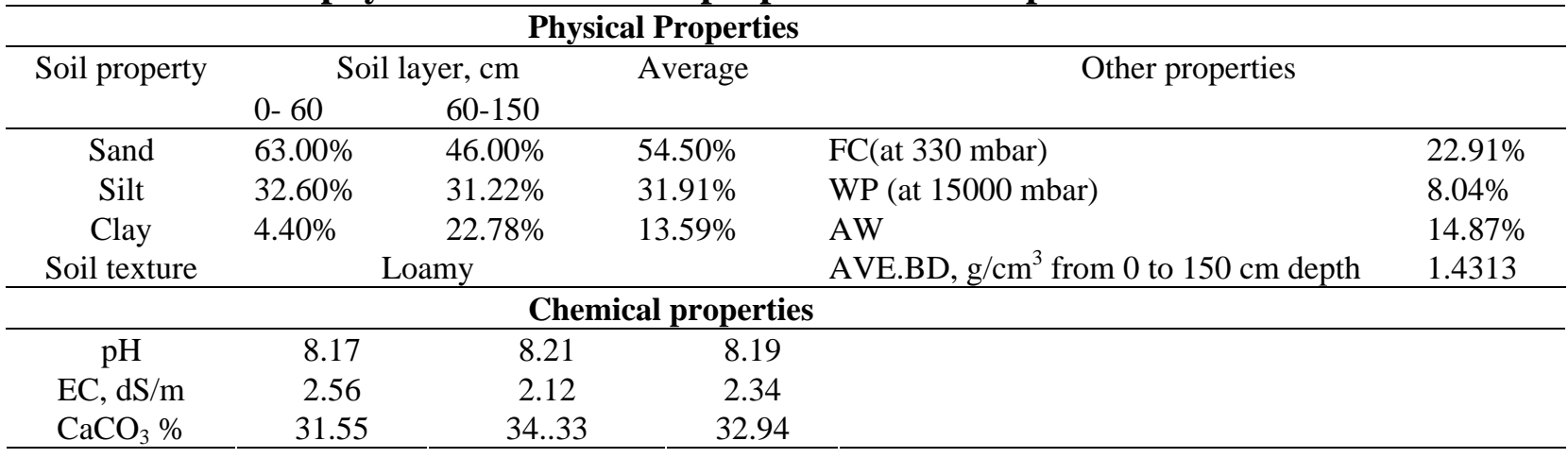




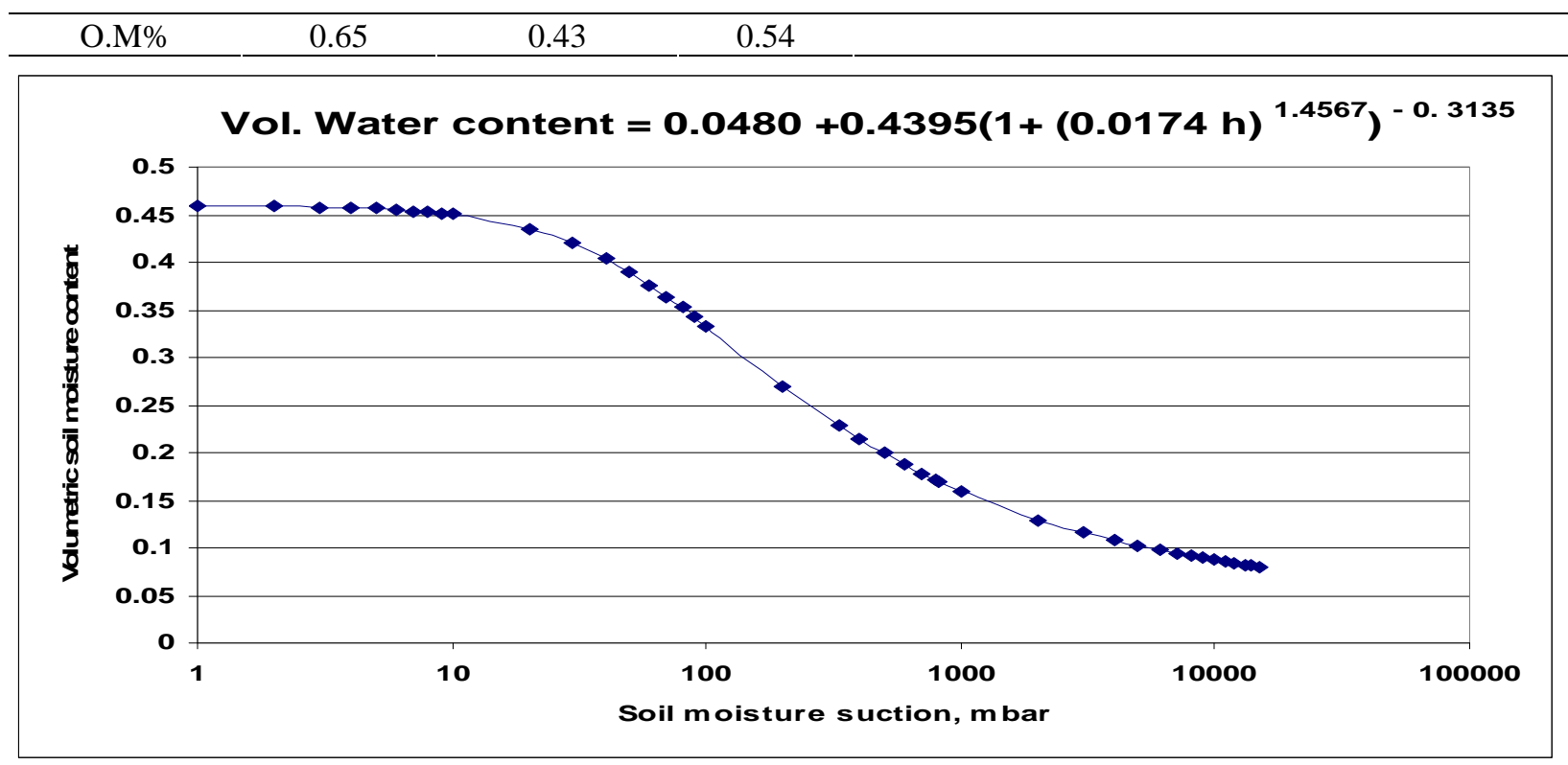

Fig. 1. Soil moisture retention curve of the soil under study

Table 2. Irrigation treatments, which were used in this study

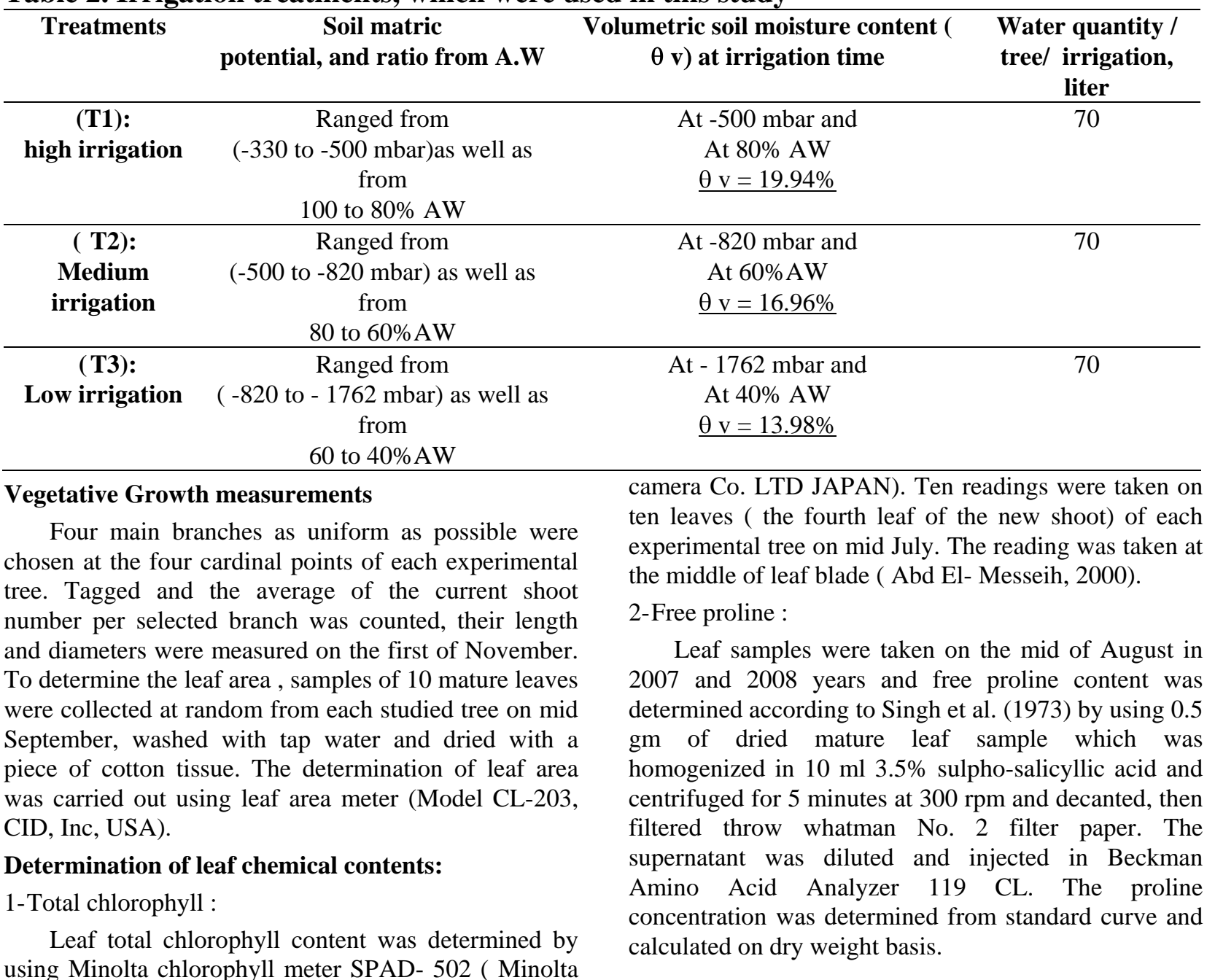




\section{3-Mineral composition:}

Twenty mature leaves were collected at random, at mid of June in the two studied seasons. The leaves were washed several times with tap water, rinsed three times in distilled water, and then dried at $70-80{ }^{\circ} \mathrm{C}$ in an electric air - drying oven.

The dried leaves of each sample were ground, 0.3 gm from the ground dried material of each sample was digested with $\mathrm{H}_{2} \mathrm{O}_{2}$ and $\mathrm{H}_{2} \mathrm{SO}_{4}$ according to Evenhuis and Dewaard (1980). Suitable aliquots were then taken for minerals determination. Total nitrogen and phosphorus were determined colorimetrically according to Evenhuis (1976), and Murphy and Riley (1962), respectively. Potassium was determined against a standard, using air propane flame photometer (Chapman and Pratt, 1961).Calcium and magnesium were measured, using versinate method (Chang and Bray, 1951) and iron, manganese and zinc by a Perkin- Elmer atomic absorption spectrophotometer Model 305-B. the concentrations of nitrogen, phosphorus, potassium, magnesium and calcium were expressed as percent, while those of iron, manganese and zinc were expressed as parts per million (ppm) on dry weight basis.

\section{Yield and Fruit Quality:}

The total yield of each studied tree was determined on weight basis, in $\mathrm{Kgs}$ at the harvest time in the mid of August of both seasons. 20 mature fruit from each studied tree were taken at random to determine fruit quality, in each sample, fruit weight was recorded as (gm), fruit dimensions( length and diameter in $\mathrm{cm}$ ), firmness was determined according to Magness and Teytor (1925) pressure tester using a $5 / 16^{=}$plunger. Total soluble solids (TSS) in the juice were determined using a hand refract meter and the acidity percentage was determined according to AOAC(1980). Total sugars content was determined according to Malik and Singh (1980). Water use efficiency (WUE) was calculated according to Viets (1962) and Begg and Turner (1976) as follows:

WUE $=\left[(\right.$ Yield, $\mathrm{Kg} /$ tree. year $) /\left(\right.$ Applied water, $\mathrm{m}^{3}$ /tree. year) ], $\mathrm{Kg} / \mathrm{m}^{3}$

\section{Statistical Analysis:}

The obtained data throughout the two studied growing seasons were statistically analyzed according to Sendecor and Cochran (1990) and L.S.D test at 0.05 level was used for comparison between treatments..

\section{RESULTS AND DISCUSSION}

\section{Vegetative Growth:}

Data in Table (3) cleared that high irrigation (T1) significantly induced high shoot number, shoot length, shoot diameter and leaf area followed by medium irrigation (T2) and low irrigation (T3), in the two studied seasons. In spite of, using a huge amounts of irrigation water in $\mathrm{T}(1)$ than in $\mathrm{T}(2)$ in the two years of study, the shoot number of pear trees were not statistically significant. The drastic influence on vegetative growth attributes induced by low irrigation (T3) in both studied seasons. These data are supported by those of Chalmers et al. (1986) who reported that withholding irrigation (WI) followed by regulated deficit irrigation (RDI) reduced vegetative growth of pears by 52\%. Besides, El- Morshedy et al. (1997) mentioned that decreasing amount of irrigation water amount significantly decreased shoot growth and leaf area of "Le Conte" pear trees growing at El- Nubaria area, Bohira Governorate. In addition, Hipps (1997) reported that the consistently irrigation increased new shoots of apples compared with no irrigation. Moreover, Abd El- Messeih and El- Gendy (2004)a noted that using high irrigation rate induced significantly high TCA increase, shoot length, shoot diameter, promoted shoot number per main branches and supported leaves to increase in their area of Canino apricot trees than normal, medium and deficit irrigation, respectively.

\section{Leaf mineral composition:}

Data listed in Table (4 \&5) indicated that in both studied seasons increasing amount of irrigation water amount significantly increased leaf macro elements $(\mathrm{N}$, $\mathrm{P}, \mathrm{K}, \mathrm{Ca}$ and $\mathrm{Mg}$ ) and micro elements (Fe, Mn, and $\mathrm{Zn}$ ). The influence of all studied treatments could be arranged as the following descending: $\mathrm{T}(1)>\mathrm{T}(2)>\mathrm{T}(3)$. Many investigators supported these data. Brun et al. (1985) mentioned that pear leaf analysis revealed little effect of irrigation practice on the concentrations of $\mathrm{N}$, $\mathrm{P}, \mathrm{Ca}$ and $\mathrm{Mg}$. In addition, trees protected from rainfall by tent-like covers of polyethylene has less foliar N, P and $\mathrm{K}$ based on either concentration or amount per unit leaf area than unprotected trees, Erf and Proctor (1989). Buwalda and Lenz (1992) reported that water stress reduced the $\mathrm{N}, \mathrm{P}$ and $\mathrm{K}$ contents of apple trees cultivars." Golden Delicious, Cox's Orange Pippin and Gloster". Further more, El- Morshedy et al. (1997) noticed that the high rate of application water coincided with high leaf $\mathrm{K}$ percentage of "Le Conte" pear trees. Moreover, Abd El-Messeih and El- Gendy (2004)b reported that decreasing irrigation water amount decreased leaf $\mathrm{N}, \mathrm{P}, \mathrm{K}, \mathrm{Ca}, \mathrm{Mg}, \mathrm{Fe}, \mathrm{Mn}$ and $\mathrm{Zn}$ of Canino apricot trees planted in sandy soil.

\section{Leaf Total Chlorophyll Content:}

Table (5) cleared that low leaf total chlorophyll was found in trees grown under low irrigation treatment (T3) while, high leaf total chlorophyll was obtained from trees grown under high irrigation treatment (T1) followed by those grown under medium irrigation treatment (T2) in both studied seasons. Moreover, the 
differences among the different irrigation treatments were significant. This reaveled that decreasing the amount of irrigation water caused a significant decrease in leaf total chlorophyll which in turn, could be an indirect effect of decreasing leaf $\mathrm{N}$ and $\mathrm{Mg}$ as consequence of low irrigation. $\mathrm{N}$ and $\mathrm{Mg}$ elements are necessary for chlorophyll synthesis, Bidwell(1979) and Mengal and Kirkby (1982). Yakushiji et al. (1998) cleared that the net photosynthetic rate of leaves of Satsuma mandarin trees under moderately drought stressed and severely drought - stressed was reduced to about $1 / 3$ and $1 / 5$ of that of well watered ones, respectively. In addition, Abd El- Messeih (2000) stated that the leaf total chlorophyll content of "Anna " apple trees significantly increased with increasing irrigation rate during three experimental seasons. the same trend was found by Abd El- Messeih and El- Gendy (2004)b on Canino apricot trees.

\section{Leaf Free Proline Content:}

Data in Table (5) indicated that leaf free proline content of "Le Conte" trees grown under low irrigation treatment (T3) was significantly high followed by (T2) and (T1), in both studied seasons. In other meaning, there was a negative correlation between the irrigation rate and leaf free proline content. This indicate that deficit irrigation stimulates the biosynthesis and accumulation of this amino acid in leaves and in the same time caused a significant reduce in leaf total chlorophyll than moderate and high irrigation. In addition, the accumulation of leaf free proline content in trees under water stress( deficit irrigation) may be due to that trees could not be able to synthesize more chlorophyll and protein.

These data are in general agreement with many previous researches, Stewart (1972) mentioned that water stress is associated with wilting which induces an increase of non-protein proline formation in bean leaves. Same trend was indicated by Hussein (1998) on apples. Also, under sever water stress $(100 \%$ depletion)seedlings synthesized about ten folds of proline values as compared with those grown under favorable water condition, Draz (1986) on bitter almond and Abd El- Motelb(1991)on grapevine. In addition, decreasing irrigation water level significantly increased leaf free- proline, Abd El- Messeih (2000) on "Anna" apples and Abd El- Messeih and El- Gendy(2004) b on "Canino " apricot trees.

\section{Yield and Fruit Quality:}

Data in Table (6) cleared that as irrigation water amount applied per tree decreased fruit yield/tree decreased. The highest fruit yield was obtained from tree grown under (T1) high irrigation (42.38 and 46.33 $\mathrm{Kg} /$ tree) followed by those of trees grown under (T2) medium irrigation (36.27 and $39.76 \mathrm{Kg} /$ tree) and those of trees grown under (T3) low irrigation (28.01 and $31.16 \mathrm{Kg} /$ tree) in 2007 and 2008 , respectively. The differences between all studied treatments were statistically significant. In addition, the reduction in fruit yield was $14.4 \%$ and $14.20 \%$ for (T2) and was $33.9 \%$ and $32.7 \%$ for (T3) than trees grown under (T1) in the first and second season, respectively. Many researches supported these data, Hipps (1997) reported that the total yield of Lobo apples from irrigated trees was $22.3 \%$ higher than this from no irrigated ones. In addition, Prazak (1992); Velickovic and Jovanovic (1993) and Holzapfel et al. (1995) reported that increasing irrigation water rate increased yield of apples.

Data in Table (6) indicated that length, diameter and weight of fruit significantly increased with increasing applied irrigation water rate while, fruit firmness was decreased in both studied years. All differences between treatments were statistically significant except fruit firmness between (T1) and (T2) only. As for chemical properties (fruit acidity $\%$, TSS\% and total sugars $\%$ ) it was found a negative correlation between applied irrigation water rate and this parameters ( Table 7). In other meaning, fruit of trees grown under (T3) have high acidity\%, TSS\% and total sugars\% followed by medium irrigation (T2) and (T1) high irrigation, respectively. These data agreed with many investigators. Yakushiji et al. (1996) mentioned that when Satsuma mandarin trees were grown under mulch cultivation, the total sugar contents of fruit were significantly higher than in well- watered fruit at harvest. In addition, Yakushiji et al. (1998) reported that fruits of Satsuma mandarin trees under severely drought stressed have significantly high (acidity \%) and (SSC\%) followed by these of trees under moderately drought and under well watered ones, respectively. Also, they found that ( the total pulp sugar content " $g$ " ) was significantly high in fruit of trees under moderately drought (stressed) than of trees under well watered. Moreover, El Morshedy et al. (1997) stated that decreasing irrigation water to $75 \%$ of the control increased Juice TSS \% and sugars content of fruits of "Le Conte" pear trees.

\section{Water Use Efficiency (WUE) :}

Data in Table (7) indicated that trees planted under high irrigation (T1) induced significantly high water use efficiency (WUE) followed by (T2) and (T3), respectively in both studied seasons( the differences between (T1) \& (T2) in 2007 were not statistically. In other meaning, (WUE) was increased parallel to increasing the amount of irrigation water. Thus trees grown under (T1) induced good vegetative growth, high 
fruit yield of good fruit quality beside high WUE than (T2) and (T3) in both studied seasons. It is considered more economic if the outcome and income was taken in consideration. These data agreed with that of Storchus \& Kosykh (1983) on peach, Abd El- Messeih (2000) on apples and Abd El- Messeih \& El - Gendy (2004) bon Apricots.

\section{Irrigation Scheduling:}

Data in Table (8) indicated that under (T1) tree received 12880 and 12915 liters in 2007 and 2008, respectively. Tree under (T2) received $10920 \& 12390$ liters, while tree under (T3) received 8960 \& 10430 liters in 2007 and 2008, respectively. In addition under all tested treatments trees used the lowest water quantity on January, increased gradually till August then decreased gradually again till November in the two studied years. This scheduling is considered fixed because of using manometers, which determine when we must irrigate trees depending on soil matric potential measurements. Tables (7,8 and 9) and Figs. (1 and 2) cleared the behavior of used irrigation water by "le Conte" pear trees in this study.

\section{Plant and Water relationship:}

Table (8) and Figs. (2, 3 \& 4) illustrate the relationship between months and the depleted applied water under the three treatments among both seasons $2007 \& 2008$ of "Le Conte" pear trees. The depleted water increases gradually with month sequences from January to July to reach the maximum at mid July, after that it decreases gradually till November. This trend was found for the three water treatments (T1, T2, and T3). These figures illustrated also, that the water depletion rate was as follows :: $\mathrm{T}(1)>\mathrm{T}(2)>\mathrm{T}(3)$

It is worthy to mention that the depleted water calculated from tree area around the tree, which was $\left(125 \times 150=18750 \mathrm{~cm}^{2}=1.875 \mathrm{~m}^{2}\right)$ and from soil volume around the tree equal to $(125 \mathrm{X} \quad 150 \mathrm{X} \quad 150$ $\left.=2812500 \mathrm{~cm}^{3}=2.8125 \mathrm{~m}^{3}\right)$. The same trend was used for the two seasons (2007 \&2008)

\section{Table 3. Effect of irrigation treatments on the vegetative growth of "Le Conte"pear trees} during 2007and 2008

\begin{tabular}{|c|c|c|c|c|c|c|c|c|c|c|}
\hline \multirow{2}{*}{$\begin{array}{l}\text { Irrigation } \\
\text { treatments }\end{array}$} & \multicolumn{2}{|c|}{ SMP $^{\#}$, mbar } & \multicolumn{2}{|c|}{ Shoot Number } & \multicolumn{2}{|c|}{ Shoot length, cm } & \multicolumn{2}{|c|}{ Shoot diameter, cm } & \multicolumn{2}{|c|}{ Leaf area, $\mathrm{cm}^{2}$} \\
\hline & from & to & 2007 & 2008 & 2007 & 2008 & 2007 & 2008 & 2007 & 2008 \\
\hline $\begin{array}{l}\text { High } \\
\text { Irrigation } \\
\text { (T1) } \\
\end{array}$ & -330 & -500 & 14.6 & 15.8 & 88.7 & 92.4 & 1.2 & 1.4 & 31.42 & 33.52 \\
\hline $\begin{array}{l}\text { Medium } \\
\text { irrigation } \\
\text { (T2) }\end{array}$ & -500 & -820 & 13.8 & 14.9 & 73.6 & 77.8 & 0.9 & 1.1 & 28.26 & 29.77 \\
\hline $\begin{array}{l}\text { Low } \\
\text { irrigation } \\
\text { (T3) severe } \\
\text { stress }\end{array}$ & -820 & -1762 & 13.7 & 14.5 & 59.8 & 65.6 & 0.7 & 0.8 & 24.18 & 25.21 \\
\hline LSD at 0.05 & $\begin{array}{ll}----- \\
-\end{array}$ & ------ & 0.9272 & 1.3286 & 1.0386 & 1.7323 & 0.0739 & 0.0661 & 1.6229 & 2.0157 \\
\hline
\end{tabular}

\# Soil matric potential

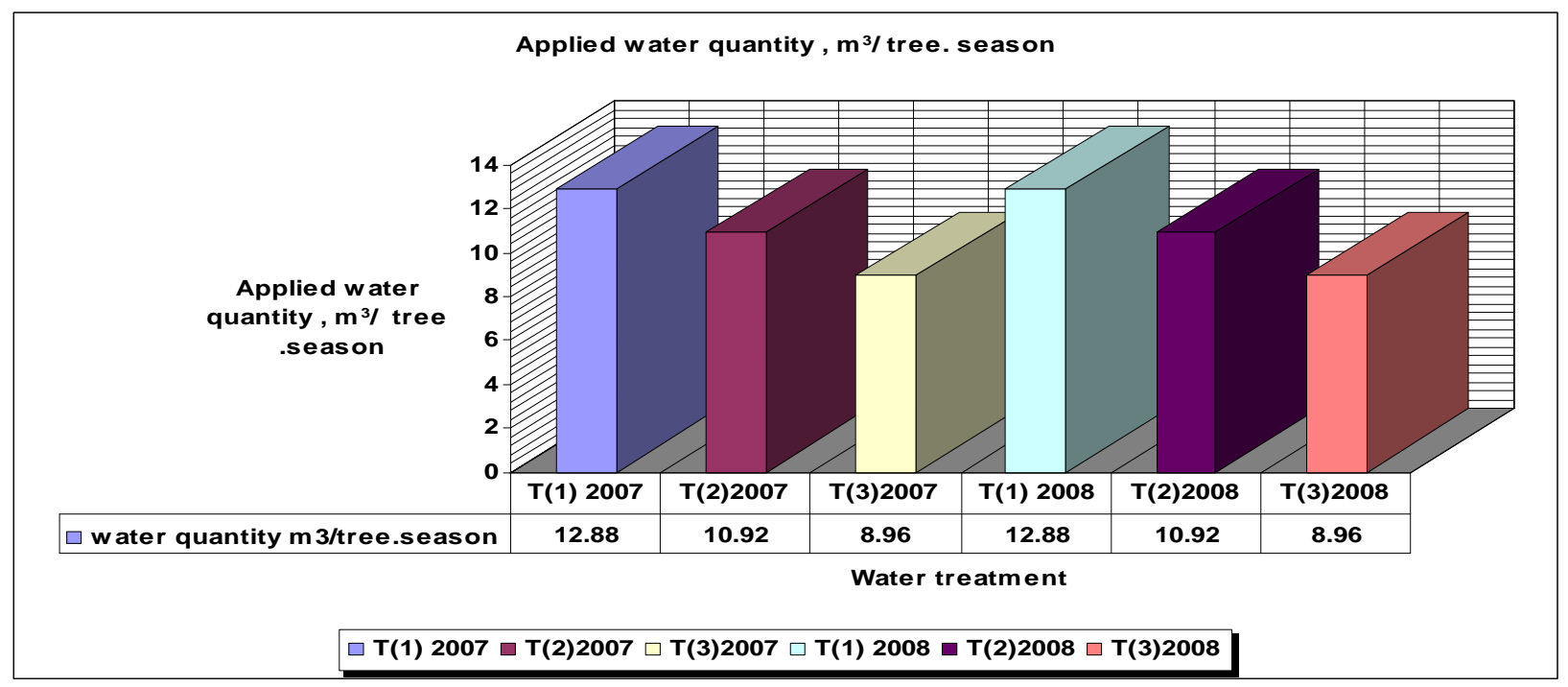


Fig. 2. Applied water quantity for "Le Conte" pear trees under the three treatments (T1, T2, and T3) during the two grown seasons (2007 \&2008) 


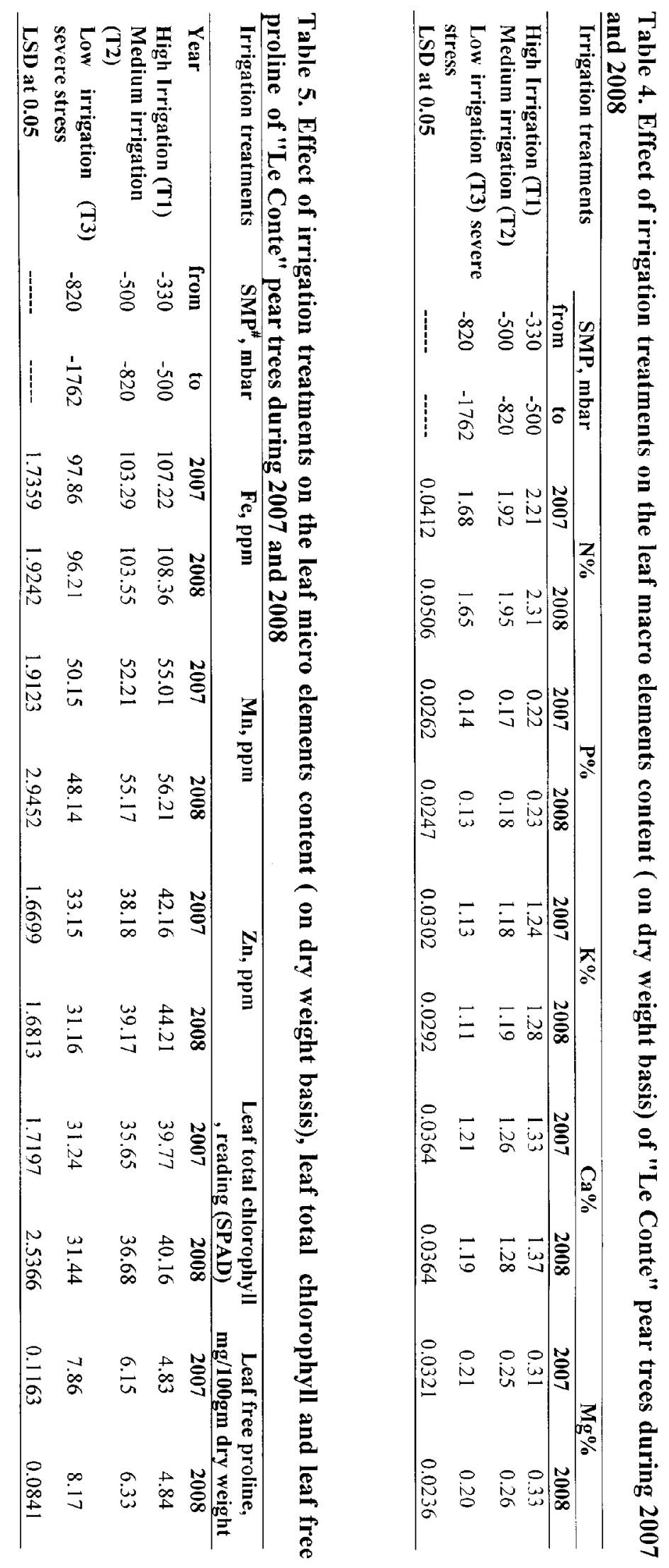



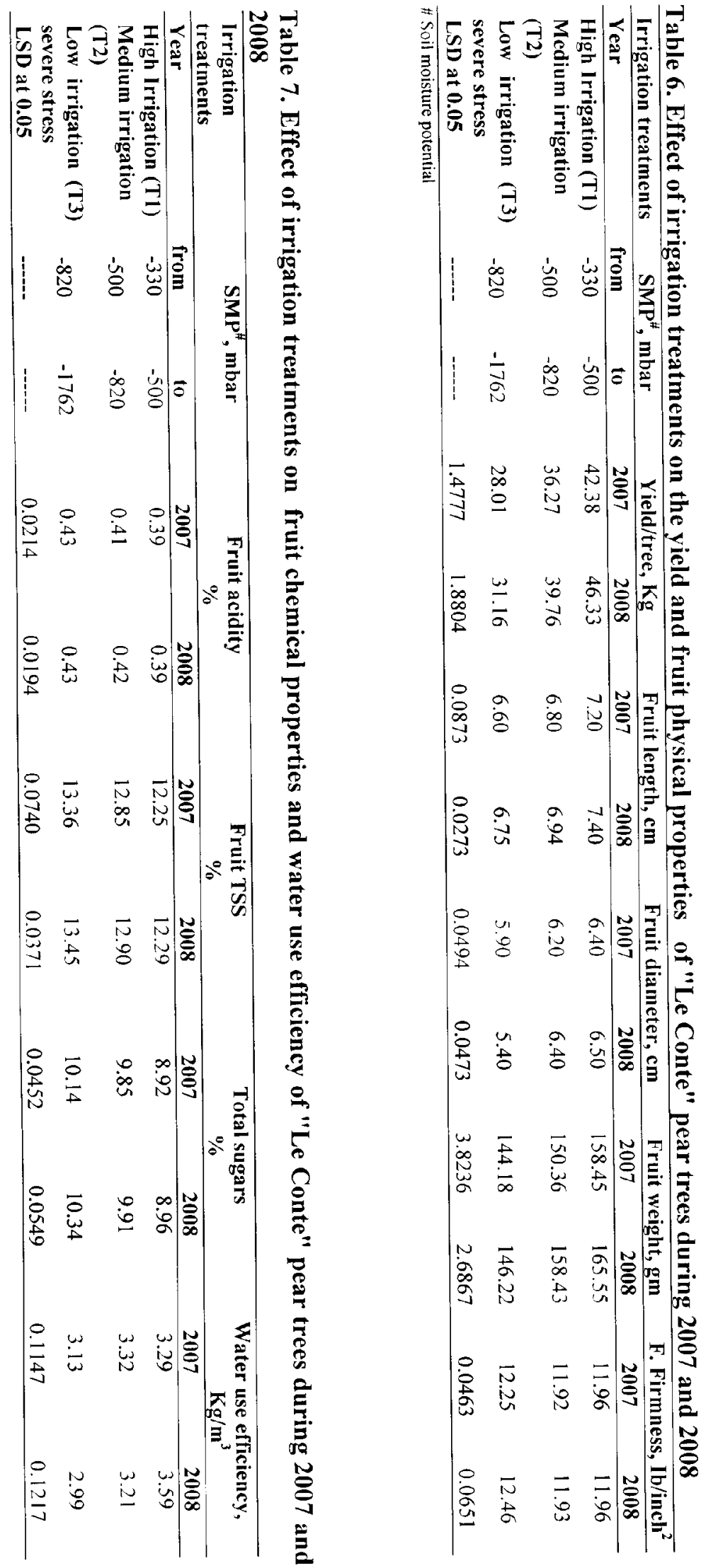

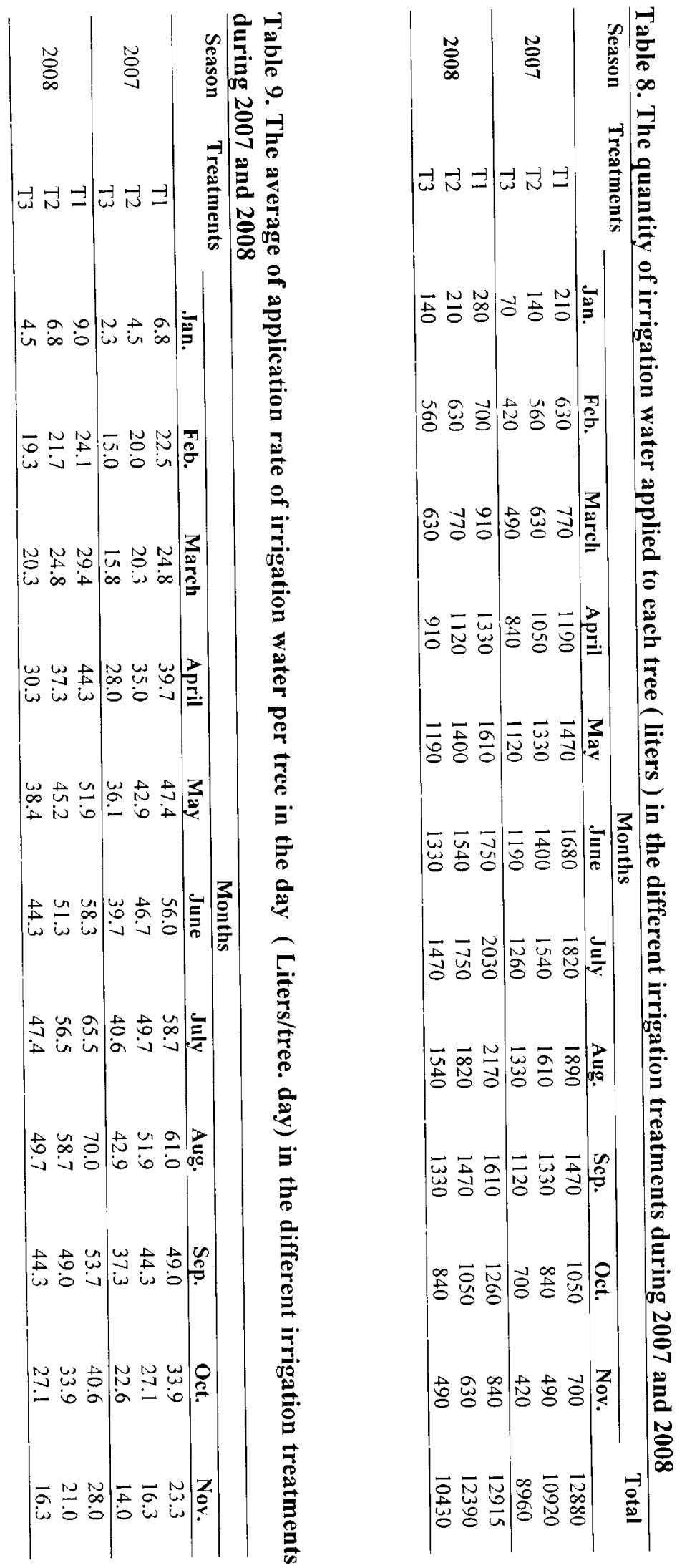


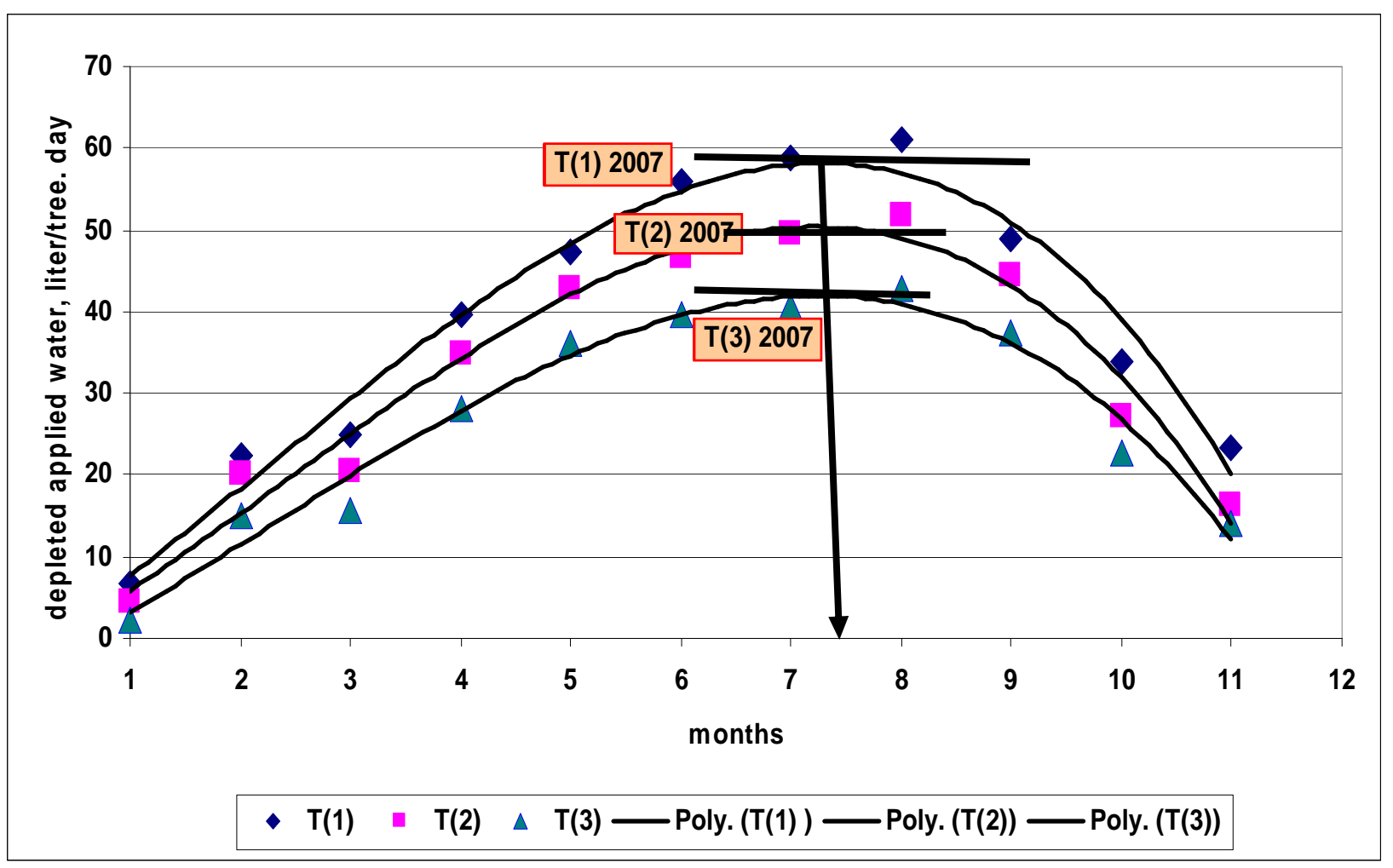

Fig. 3. The depleted irrigation water curves of "Le Conte" pear trees under the three studied treatments during 2007

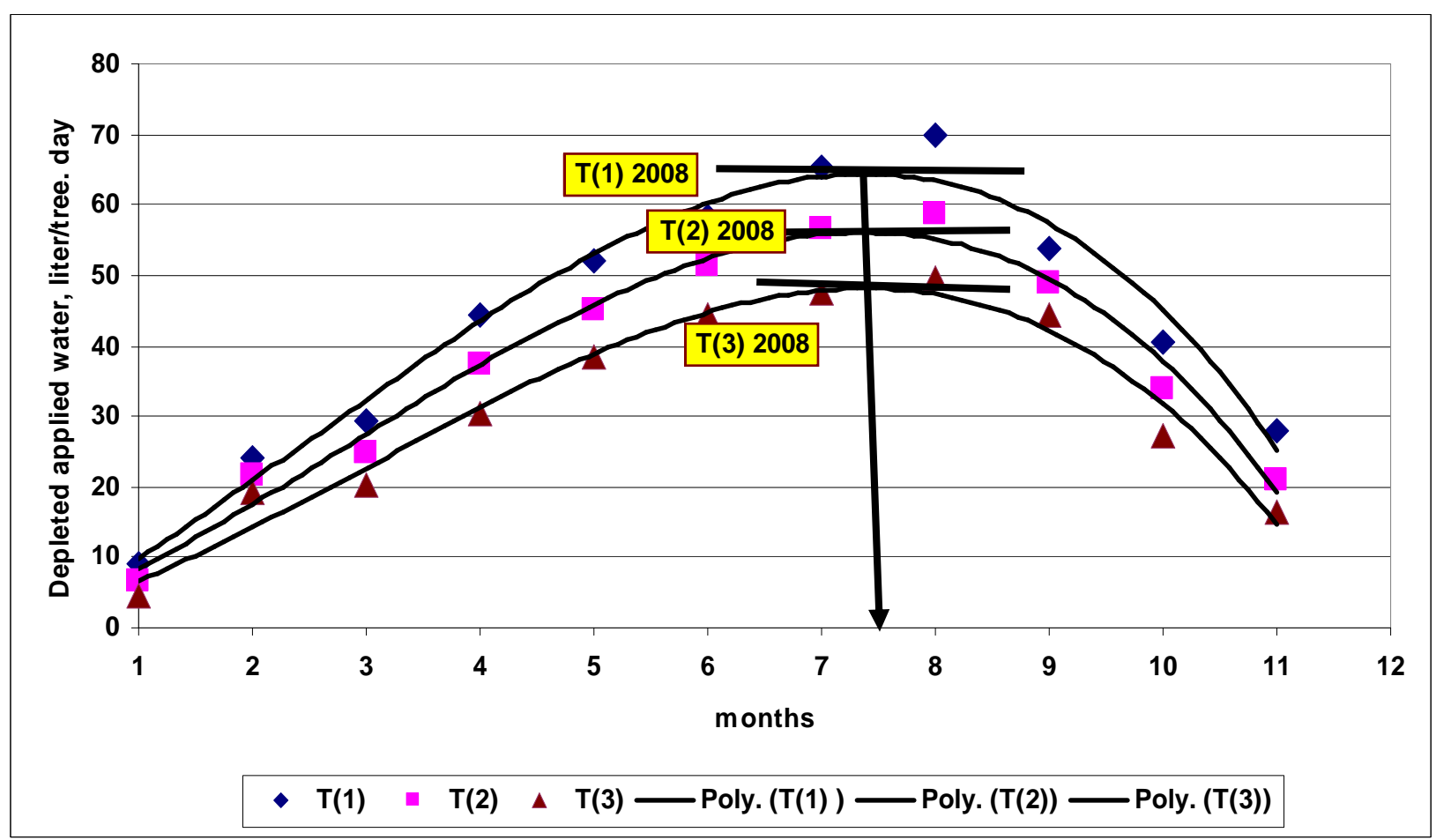

Fig. 4. The depleted irrigation water curves of "Le Conte" pear trees under the three studied treatments during 2008 
Depleted water in the three water treatments represented in the following polynomial functions with high coefficient determination:

$\mathrm{Y}(\mathrm{T} 1$ at 2007$)=-0.1464 \mathrm{X}^{3}+1.0008 \mathrm{X}^{2}+8.7276 \mathrm{X}-$ 1.947, $\quad \mathrm{R}^{2}=0.9691$

$\mathrm{Y}\left(\mathrm{T} 2\right.$ at 2007) $=-0.1361 \mathrm{X}^{3}+0.9437 \mathrm{X}^{2}+7.6116 \mathrm{X}-$ 2.5864, $\quad \mathrm{R}^{2}=0.9661$

$\mathrm{Y}\left(\mathrm{T} 3\right.$ at 2007) $=-0.1114 \mathrm{X}^{3}+0.7275 \mathrm{X}^{2}+6.9858 \mathrm{X}-$ $4.5258, \quad \mathrm{R}^{2}=0.9677$

$\mathrm{Y}(\mathrm{T} 1$ at 2008$)=-0.1642 \mathrm{X}^{3}+1.2471 \mathrm{X}^{2}+8.4037 \mathrm{X}$ $+0.3833, \quad \mathrm{R}^{2}=0.9688$

$\mathrm{Y}\left(\mathrm{T} 2\right.$ at 2008) $=-0.1612 \mathrm{X}^{3}+1.3549 \mathrm{X}^{2}+6.2646 \mathrm{X}$ $+0.8606, \quad R^{2}=0.9786$

$\mathrm{Y}\left(\mathrm{T} 3\right.$ at 2008) $=-0.154 \mathrm{X}^{3}+1.4098 \mathrm{X}^{2}+4.3699 \mathrm{X}$ $+1.0121, \quad \mathrm{R}^{2}=0.9678$

Where:

$\mathrm{Y}$ : is the depleted water, liter/tree. Day

$\mathrm{X}$ : is the number of the month of the growth season

According to the soil moisture stress within the treatments, applied water was in gradually decreasing from high at $\mathrm{T}(1)$ to Low at (T3) through the two growing seasons (2007 \&2008) as shown in Fig. (2),

\section{CONCLUSION}

Using a huge amount of irrigation water has a drastic effect on both soil and trees grown in the soil beside using more costs. In order to use the correct amounts of irrigation water without causing damage for both of soil and trees or reduce vegetative growth and yield of good quality of trees, we must schedule irrigation via the soil matric potential near field capacity. This technique depending on soil matric potential measurements using tensiometers and has many advantages for " Le Conte" pear trees such as induced good vegetative growth, good yield of good fruit quality and high water use efficiency beside saving irrigation water.

\section{REFERENCES}

Abd El- Messeih, W. M. (2000). Response of "Anna" apple trees to different irrigation treatments combined with three nitrogen levels for scheduling irrigation and saving water in new reclaimed soil. Ph.D. Thesis, Fac. of Agric., Alex. Univ., Egypt.

Abd El- Messeih, W. M. and R. W. El- Gendy (2004) a. Effect of different trickle irrigation levels based on soil matric potential on: 1- Vegetative growth and yield of "Canino" apricot trees planted in sandy soil. Alex. Sci. Exch., Vol. 25 No. 3, pp. 465-480.

Abd El- Messeih, W. M. and R. W. El- Gendy (2004) b. Effect of different trickle irrigation levels based on soil matric potential on: 2- Leaf chemical composition and active rooting depth of " Canino" apricot trees planted in sandy soils. Alex. Sci. Exch., Vol. 25 No. 3, pp. 481-495.

Abd El-Motelb, M.M.M.(1991). Physiological and anatomical studies on grapevine transplant as affected by different irrigation treatments. M.Sc. Thesis, Fac.of Agric. Ain Shams Univ., Egypt.

Association of official agricultural Chemists. (1980). Official methods of analysis ( The A. O. A. C. $13^{\text {th }}$ ed. Washington, D. C. U. S. A.).

Begg, J. E. and N. C. Turner (1976). Crop water deficits. Advances in Agron. 28: 189 - 197.

Bidwell, R.G.S. (1979). Plant physiology - Mc Millan an publishing Co.,

INC. New York. 430 p.

Black, C.A. (ed.) (1965). Methods of soil analysis. Amer. Soc. Agron. Inc

Pub. Madison, Wisconsin.

Brun, C.A.; J.T. Raese and E.A. Stahly (1985). Seasonal response of "Anjou" pear trees to different irrigation regimes. II- Mineral composition of fruit and leaves, fruit disorders, and fruit set. J. Amer. Soc. Hort. Sci. 110 (6): 835-840.

Buwalda, J. G. and F. Lenz (1992). Effects of cropping, nutrition and water supply on accumulation and distribution of biomas and nutrients for apple trees on M.9 root system-Phusiologia-Plantarum. 84 (1): 21-28.

Chang, K.L. and R.H. Bray (1951). Determination of calcium and magnesium in soil and plant materials. Soil Sci. 72: 449-458.

Chalmers, D.J.; G. Burge; P.H. Jerie and P.D. Mitchell (1986). The mechanism of regulation of "Bartlett" pear fruit and vegetative growth by irrigation withholding and regulated deficit irrigation. J. Amer. Soc. Hort. Sci. 111 (6): 904-907.

Chapman, H.D. and P.F. Pratt (1961). The Method of analysis for soill, plant and waters. Univ. Calif. Div. Agric. Sci., Riverside California.

Draz, M. Y. (1986). Response of bitter almond seedlings to different water regimes. Ph.D. Thesis, Fac. of Agric. Cairo Univ., Egypt.

Elfving, D. C. (1982). Hort. Rev. 4. : 1 -48.

El- Gendy, R. W. (2006): Estimating Some Plant Concepts Relevant with Water and Soil by Using Neutron Probe. Eighth Arab Conference on the Peaceful Uses of Atomic Energy, Amman, 3-7 December 2006

El- Morshedy, F. A.; A. M. El. Kobbia and M. M. Sourour (1997). Response of "Le Conte" pear trees to different irrigation rates. J. Agric. Res. Tanta Univ. 23(2): $184-$ 197.

Erf, J. A. and J. T. A. Proctor (1989). Growth, leaf mineral nutrition, and water status of mature apple trees subjected to various crop loads and soil water conditions. J. Amer Soc, Hort. Sci. 114(20): 191- 196. 
Evenhuis, B. (1976). Nitrogen determination. Dept. Agric. Res., Royal Tropical Inst. Amesterdam.

Evenhuis, B , and P.W. Dewaard (1980). Principles and Practices in plant analysis. FAO soil Bull. 38(1): $152-$ 163.

Gyuro, F. (1974). A Gyumo/ cstermesztes alapjal. Budapest: Mezogadasag:Kiado.

Hipps, N. A. (1997). Effect of nitrogen, phosphorus, water and pre- planting soil fertilization on growth and yield ofQueen cox/M.9 apple trees. Acta Horticulture No. 9, 448: 125-131.[Hort. Abst., 68 (9):7412].

Holzapfel, H.E.; G.G. Figueroa; V.A. Venegas and C.R. Matta (1995). Water requirements in mature apple trees. AgroCiencia ii (1) : 49- 54. [ Hort. Abst., 67 (1): 101].

Hussein, S. M. M.(1998). Influence of irrigation levels on the growth, mineral content; and fruit quality of "Anna" apples. M.Sc. Thesis, Fac. of Agric. Cairo Univ. , Egypt.

Magness, J. R. and G. F. Taylor ( 1925). An improved type of pressure tester for the determination of fruit maturity. $U$. S. Dept. Agric. Circ. 350, 8 pp.

Malik, C. P. and M. B. Singh (1980). Plant enzymology and histoezymology. A Text Manual. Kalyani, Publishers, New Delhi.

Mengel, K. and E. A. Kirkby (1982). Principal of plant nutrition. Bern. Switzerland. Int. Potash Inst., P. 520.

Murphy, J. and L.P. Riley (1962). A modified single solution method for the determination of phosphorus in mineral water. Anal. Chim. Acta. 27: 31-36.

Prazak, M. (1992). The effects of controlled sprinkling irrigation on apple yields and economic aspects of appletree growing. Screntia Agriculturae Bohemoslovacia. 24 (2): 107-112.

Richards, D. (1976). Ann. Bot. 41: 279-281.

Richards, D. and R.N. Rowe (1976). Ann. Bot. 41: 1211-1216.
Sendecor, G.W, and W.G.Cochran (1990). Statistical methods. $7^{\text {th }}$ ed. The Iowa state Univ. Press. Ames. Iowa USA. P. 593.

Singh,T.N.; L.G. Poleg and D. Aspinall (1973). Stress metabolism. 1. Nitrogen metabolism and growth in the barley plant during water stress. Augst. J.Biol. Sci. (26) : $45-56$.

Stewart,C.R. (1972). The effect of wilting on proline metabolism in excised bean leaves in the dark. Plant Physiol. $51: 508$ - 651.

Storchus, V.N. and S.A.Kosykh (1983). Growth and development of drip irrigated peach in the steppe Grimea. Bull.Gos-Nik-Botan-Sada,50 : 51 - 56 . (C.F.Hort.Abst. 53:2803).

Taylor,S.A. (1965). Maniging irrigation water on the farm. Amer. Soc.Agr. Eng. Trans. 8: 433 - 436.

Van Genuchten, M.T. (1980). A closed form equation for predicting the hydrolic conductivity of unsaturated soil. Soil Sci. Soc. Am. J., 44: 513 - 522.

Velickovic, M. and M. Jovanovic (1993). Irrigation effects on the fertility of some major apple cultivars governed by dense planting and irregular palmetto. Review of Research work at the Fac. Of Agric. Belgrade 38 (1) : 99 - 102. [Hort. Abst., 64 (7) : 5184].

Viets, F. G. (1962). Fertilizers and the efficient use of water. Advan. Agron. 14; 228 - 261.

Yakushiji, H., H. Nonami; T. Fukuyama; S. Ono; N. Takagi and Y. Hashimoto (1996). Sugar accumulation enhanced by osmoregulation Satsuma mandarium fruit. J. Amer. Soc. Hort. Sci. 121: 466 - 472.

Yakushiji, H., K. Morinaga and H. Nonami (1998). Sugar accumulation and partitioning in Satsuma mandarin tree tissue and fruit response to drought stress. J. Amer. Soc. Hort. Sci. 123 (4) : 719 - 726 


\section{الملخص العربي}

\section{جدولة الري بالتنقيط باستخدام طريقة جهد الشد الرطوبي الأرضى لأشجار الكمثري"ليكونت" المتزرعة في الأراضي الجيرية \\ وصفي ماهر عبد المسيح، رشدي واصف الجندي}

الثمرة) و كذلك أعطت أعلى كقاءة اســتخدام للميـــاه

(WUE); أيضا هذه الاشجار أعطت أعلى محتوى معدلى في ولى

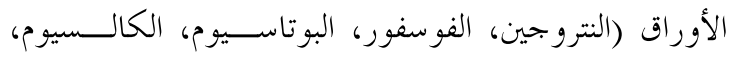
الماغنسيوم، الحديد، المنجنيز، الزنك ) وأعلى كلوروفيل كلى في الأوراق تلتها اشجار المعاملة (T2) ( من • • - . ب\% من الماء الميسر) ثم أشجار المعاملة (T3) ( من • ج - . ع \% مــن الماء الميسر) على التوالى في كلا من الموسمين. - على الجانب الاخر فان الأشجار النامية تحت (T3) أعطــت

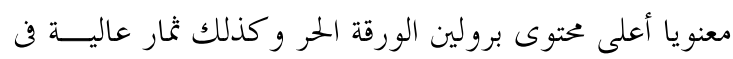
صلابتها ومحتواها من الحموضة\% و و المواد الــصلبة الذائبـــة (TSS\%) تحت (T2) و (T3) على التوالى في موسمى الدراسة. بناءا على النتائج السابقة فان معاملة الرى(T1) يوصى بها في رى الكمثرى"ليكونت" المتررعة في الأراضى الجيرية في منطقة برج العرب (مصر) باستخدام نظام الرى بالتنقيط المحدول على أساس قياس الشد الرطوبى الأرضى باستخدام التنشيومترات.

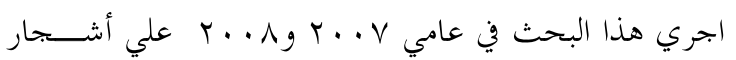
الكمثري صنف "ليكونت" عمر ست سنوات والمطعومه علي أصل

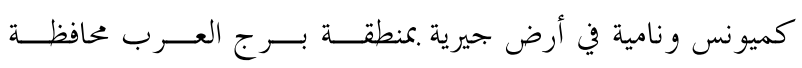
الاسكندرية.

هدف هذا العمل هو بحث تأثير ثلاثة معدلات ري مبنية علي أساس قياسات الشد الرطوبي الأرضي. وهذه المعاملات هي: (T) معدل ري عالي: الري ما بين - .بrا، - . ..0 ملي بــار، (T2)

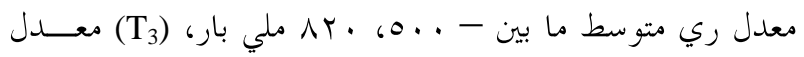
ري منخفض : الري ما بين - · IVTr - ملي بار علي النمو الخضري والمحتوي المعدلن للاوراق والمصصول وصفات جودة الثمار

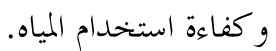

النتائج الرئيسية لهذا العمل يمكن تلخيصها في النقاط التالية: ـ

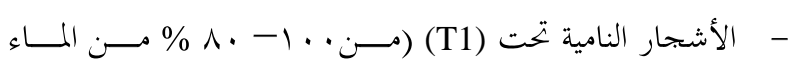

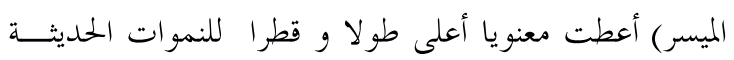
ومساحة للورقة ومحصول الثمار وصفات جودة ( طول وقطر 
